\title{
Adjuvant Selection for Influenza and RSV Prefusion Subunit Vaccines
}

\author{
Ariel Isaacs ${ }^{1}{ }^{(}$, Zheyi $\mathrm{Li}^{2}$, Stacey T. M. Cheung ${ }^{1}{ }^{(0}$, Danushka K. Wijesundara ${ }^{3}$, Christopher L. D. McMillan ${ }^{1}(\mathbb{D}$, \\ Naphak Modhiran ${ }^{1}{ }^{-}$, Paul R. Young ${ }^{1,3,4}$, Charani Ranasinghe ${ }^{2}$, Daniel Watterson ${ }^{1,4}$ and Keith J. Chappell $1,3,4, *$
}

1 School of Chemistry and Molecular Biosciences, The University of Queensland, St Lucia, QLD 4072, Australia; a.isaacs@uq.edu.au (A.I.); s.cheung@uq.edu.au (S.T.M.C.); c.mcmillan1@uq.edu.au (C.L.D.M.); n.modhiran@uq.edu.au (N.M.); p.young@uq.edu.au (P.R.Y.); d.watterson@uq.edu.au (D.W.)

2 Department of Immunology and Infectious Disease, The John Curtin School of Medical Research, The Australian National University, Canberra, ACT 2601, Australia; zheyi.li@anu.edu.au (Z.L.); charani.ranasinghe@anu.edu.au (C.R.)

3 The Australian Institute for Biotechnology and Nanotechnology, The University of Queensland, St Lucia, QLD 4072, Australia; d.wijesundara@uq.edu.au

4 Australian Infectious Disease Research Centre, The University of Queensland, St Lucia, QLD 4072, Australia

* Correspondence: k.chappell@uq.edu.au

Citation: Isaacs, A.; Li, Z.; Cheung, S.T.M.; Wijesundara, D.K; McMillan, C.L.D.; Modhiran, N.; Young, P.R; Ranasinghe, C.; Watterson, D.; Chappell, K.J Adjuvant Selection for Influenza and RSV Prefusion Subunit Vaccines. Vaccines 2021, 9, 71. https://doi.org/10.3390/vaccines 9020071

Academic Editor: Andrew Pekosz Received: 31 December 2020

Accepted: 18 January 2021

Published: 20 January 2021

Publisher's Note: MDPI stays neutral with regard to jurisdictional claims in published maps and institutional affiliations.

Copyright: (c) 2021 by the authors. Licensee MDPI, Basel, Switzerland. This article is an open access article distributed under the terms and conditions of the Creative Commons Attribution (CC BY) license (https:/ / creativecommons.org/licenses/by/ $4.0 /)$.

\begin{abstract}
Subunit vaccines exhibit favorable safety and immunogenicity profiles and can be designed to mimic native antigen structures. However, pairing with an appropriate adjuvant is imperative in order to elicit effective humoral and cellular immune responses. In this study, we aimed to determine an optimal adjuvant pairing with the prefusion form of influenza haemagglutinin (HA) or respiratory syncytial virus (RSV) fusion (F) subunit vaccines in BALB/c mice in order to inform future subunit vaccine adjuvant selection. We tested a panel of adjuvants, including aluminum hydroxide (alhydrogel), QS21, Addavax, Addavax with QS21 (AdQS21), and Army Liposome Formulation 55 with monophosphoryl lipid A and QS21 (ALF55). We found that all adjuvants elicited robust humoral responses in comparison to placebo, with the induction of potent neutralizing antibodies observed in all adjuvanted groups against influenza and in AdQS21, alhydrogel, and ALF55 against RSV. Upon HA vaccination, we observed that none of the adjuvants were able to significantly increase the frequency of $\mathrm{CD}^{+}$and $\mathrm{CD} 8^{+} \mathrm{IFN}-\gamma^{+}$cells when compared to unadjuvanted antigen. The varying responses to antigens with each adjuvant highlights that those adjuvants most suited for pairing purposes can vary depending on the antigen used and/or the desired immune response. We therefore suggest that an adjuvant trial for different subunit vaccines in development would likely be necessary in preclinical studies.
\end{abstract}

Keywords: adjuvant; vaccine; influenza; RSV; microbiology; virology

\section{Introduction}

Since the use of vaccination to eradicate smallpox, vaccines have emerged as a powerful tool for prevention and control of existing and emerging pathogens. Numerous vaccines have rapidly emerged amidst the COVID-19 pandemic for clinical validation, allowing the comparison of inactivated, recombinant viral, mRNA, and subunit vaccine platforms for safety and immunogenicity in completed Phase I trials that have been published following peer review [1]. From this analysis, subunit vaccines exhibited the most favorable safety and immunogenicity profile [1]. Subunit vaccines possess a high safety profile due to the lack of viral replication, no risk of incomplete inactivation, no live virus components, and minimal side effects [2,3]. Furthermore, subunit vaccines can be rationally designed to a specific conformation to mimic the pathogen structure and elicit a potent neutralizing antibody response.

Adjuvants are pivotal in enhancing the immune responses elicited against protein subunits. There are numerous good manufacturing practice (GMP)-compatible and scal- 
able adjuvants that can be co-delivered with subunit vaccines to tailor type 1 and/or type $2 \mathrm{~T}$ - and B-cell responses that represent immune correlates of natural recovery or resolution of infection [4-7]. Aluminum salts (hereafter referred to as alum) are the most widely used adjuvants in vaccines, with a strong safety profile shown following hundreds of millions of doses administered in humans [8-10]. Alum is thought to act through a combination of local inflammation, the depot effect, and increased uptake of antigen by antigen-presenting cells (APCs), leading to a T-helper 2 (Th2)-biased response [9-11]. Moreover, it is known that alum is a poor inducer of T-helper 1 (Th1) response as it does not promote the induction of IL-12 production [12,13]. In contrast, monophosphoryl lipid A (MPLA), a bacterial derivative and toll-like receptor (TLR) 4 agonist, skews the immune response towards a Th1-biased response [14-16]. When used in conjunction with alum as part of GlaxoSmithKline's (GSK) AS04, this adjuvant system is able to improve both humoral and cellular immune responses. As such, AS04 is part of vaccines against hepatitis B virus, human papillomavirus, and herpes simplex virus [14,17]. GSK has also developed additional proprietary adjuvant systems, namely AS01, AS02, and AS03. AS01, a combination of liposomes, MPLA, and saponin QS21, induces robust Th1 immune responses, enhances antigen presentation to APCs, and induces a high antibody titre [17-19]. AS02, a squalene emulsion with MPLA and QS21, induces Th1-biased response and a high antibody titre $[17,20]$. AS03, containing DL- $\alpha$-tocopherol, squalene, and polysorbate 80 , enhances vaccine-generated immune responses, particularly long-term antibody levels, through induction of $\mathrm{CD}^{+} \mathrm{T}$-cell responses [21]. An additional squalene oil-in-water emulsion that has had success as an adjuvant in human vaccines is MF59. MF59 enhances immune responses through a range of immune-stimulatory effects, including increasing the recruitment of immune cells to the injection site through induction of chemokines and enhancing the priming of naïve T-cells by increasing dendritic cell maturation [22-24]. MF59's success as a safe and potent adjuvant has led to the development of Addavax, an MF59-like squalene oil-in-water emulsion.

We have previously developed subunit vaccine candidates for both influenza and respiratory syncytial virus (RSV) [25] based on influenza haemagglutinin (HA) and RSV fusion glycoprotein (F). Current influenza vaccines are either attenuated, inactivated, and detergent-split or subunit vaccines and provide little cross-protection to other subtypes [26-28]. Because these vaccines primarily serve to boost preexisting immunity in primed populations, they are typically unadjuvanted and semi-purified, and therefore result in reduced immunogenicity in unprimed populations, such as young children [29,30]. Furthermore, egg-grown vaccines are only reliable when vaccine strains are matched with circulating strains and therefore require frequent reformulation [26-28]. For RSV, there is currently no licensed vaccine, with development hampered by the failure of an alum-adjuvanted formalin-inactivated RSV vaccine in the 1960s [31,32]. Currently, there are several candidates in clinical trials, consisting of AS01B-adjuvanted RSV F subunit vaccine [33], several alum-adjuvanted or unadjuvanted RSV F subunits [34,35], and several unadjuvanted live-attenuated or vectored RSV vaccines [36,37]. Our subunit vaccines for these viruses, currently in preclinical development, make use of a patented technology: a novel trimerization domain, the molecular clamp, that can stabilize viral fusion glycoproteins in their prefusion conformation $[25,38,39]$. The prefusion conformation allows a tailored and targeted immune response to be elicited against both conserved and highly neutralizing epitopes of the fusion protein used for immunization [40,41]. The clamp stabilization technology is broadly applicable to many viral fusion proteins and has been validated as a platform technology $[25,38,39]$. As such, we conducted an adjuvant trial to determine optimal adjuvant-antigen pairing for our clamped subunit vaccines using influenza HA and RSV F as model antigens. Here, we selected a panel of adjuvants to test with both clamp-stabilized HA (HA clamp) and clamp-stabilized RSV F (F clamp) that are analogous to what is currently approved or in clinical trials for human use, including aluminum hydroxide (alhydrogel), QS21, Addavax, Addavax with QS21 (AdQS21) and Army Liposome Formulation 55 with MPLA and QS21 (ALF55). 


\section{Materials and Methods}

\subsection{Antigen Production}

Influenza HA clamp and RSV F clamp were produced as previously described [38]. Codon-optimized DNA sequences encoding the ectodomain of HA from A/California/04/ 2009 (H1N1) (1-510, GenBank: ACP41105.1) or RSV F ectodomain (1-474, GenBank: APW29972.1) with the fusion peptide and peptide 27 deleted $(\Delta 106-150)$ were synthesized by IDT. These sequences were cloned into a mammalian expression vector upstream of a GSG-linked HIV gp41 fusion core trimerization domain using the inFusion cloning method and Stellar competent cells according to the manufacturer's protocol (TakaraBio, Shiga, Japan). Plasmid DNA sequences encoding HA clamp and F clamp were transfected and expressed using the ExpiCHO-S expression system according to the manufacturer's protocol (ThermoFisher Scientific, Waltham, MA, USA). In brief, a ratio of $1 \mu \mathrm{g}$ DNA to $1 \mathrm{~mL}$ of cultured ExpiCHO cells at a density of $6 \times 10^{6}$ cells $/ \mathrm{mL}$ was used for transfection. Seven days after transfection, cell culture supernatant was harvested by centrifugation at $4800 \times g$ for $30 \mathrm{~min}$ at $4{ }^{\circ} \mathrm{C}$ prior to filter sterilization $(0.22 \mu \mathrm{m})$ for subsequent protein purification. Protein was purified from cell culture supernatant using immunoaffinity purification with an in-house-made column embedded with a resin coupled with an anti-clamp monoclonal antibody (HIV1281). Supernatant was applied to the column, washed with high salt PBS (PBS with $400 \mathrm{mM} \mathrm{NaCl}$; $\mathrm{pH} 7.4$ ), and eluted with a high $\mathrm{pH}$ buffer (100 mM glycine, $137 \mathrm{mM} \mathrm{NaCl}$, and $5 \mathrm{mM}$ EDTA; $\mathrm{pH}$ 11.5). Eluted fractions were neutralized with a 1:1 $\mathrm{v} / \mathrm{v}$ ratio of $1 \mathrm{M}$ Tris $\mathrm{pH}$ 6.8. Protein was concentrated and buffer exchanged into PBS (Merck Amicon, Burlington, MA, USA), and the protein concentration was quantified using NanoDrop One (ThermoFisher Scientific).

\subsection{Adjuvant Formulation and Mouse Immunizations}

Adjuvants were formulated at one-tenth of the dose approved for humans. Five micrograms of antigen was formulated with either $5 \mu \mathrm{g}$ QS21 (Desert King), $50 \mu \mathrm{g}$ alhydrogel (Brenntag), $1.25 \mathrm{mg}$ Addavax (Invivogen), $5 \mu \mathrm{g}$ QS21 with $1.25 \mathrm{mg}$ Addavax (AdQS21; Desert King/Invivogen), or $5 \mu \mathrm{g}$ QS21 with $300 \mu \mathrm{g}$ liposomes containing $5 \mu \mathrm{g}$ MPLA (ALF55, Avanti Polar Lipids Inc., Alabaster, AL, USA).

Female BALB/c mice aged 5-8 weeks were sourced from the Australian Resource Centre and housed in individually ventilated, HEPA-filtered cages at the University of Queensland Biological Research facility. The mouse study was conducted in accordance with the University of Queensland Animal Ethics Committee approval (AEC SCMB/558/17). Mice were allowed to acclimatize for 1 week prior to intramuscular vaccination in the hind-leg muscle with the aforementioned adjuvant-antigen formulations, PBS placebo, or antigen alone under anesthesia. Two weeks post prime, half the mice $(n=4)$ were sacrificed for spleen harvest and cardiac puncture. A week later, blood from the remaining mice $(n=4)$ was collected via the tail vein. One day later, a booster immunization was given to the mice as before. Three weeks later, all remaining mice were sacrificed for spleen harvest and cardiac puncture. Serum from all timepoints was harvested by allowing blood to coagulate overnight at $4{ }^{\circ} \mathrm{C}$ prior to centrifugation at $10,000 \times g$ for $10 \mathrm{~min}$ at $4{ }^{\circ} \mathrm{C}$. To assess T-cell responses of each mouse, splenocytes were depleted for red blood cells and profiled for cytokine expression as described below.

\subsection{T-Cell Cytokine Profiling}

Monoclonal antibodies Brilliant Violet 421 anti-mouse CD3 clone 17A2, PE anti-mouse CD4 clone GK1.5, Brilliant Violet 650 anti-mouse CD8 clone 53-6.7, APC anti-mouse IFN- $\gamma$ clone XMG1.2, PE/Cy7 anti-mouse TNF- $\alpha$ clone MP6-XT22, and Alexa Fluor 488 antimouse interleukin-2 (IL-2) clone JES6-5H4 were obtained from BioLegend (San Diego, CA, USA). Intracellular cytokine staining was performed as described previously [42]. Briefly, $2 \times 10^{6}$ splenocytes were plated into each well and stimulated with $5 \mu \mathrm{g} / \mathrm{mL}$ HA peptide pool or DMSO (negative control) for $16 \mathrm{~h}$. Then, $5 \mathrm{~h}$ prior to the end of stimulation, $1 \mu \mathrm{g} / \mathrm{mL}$ brefeldin A (BioLegend) was added to each well. Cells were then washed with 
FACS buffer (2\% FBS in sterile DPBS) and surface staining was performed in the dark on ice for $30 \mathrm{~min}$. Cells were fixed with IC FIX buffer (BioLegend), and permeabilized with 1X permeabilization buffer (BioLegend). Intracellular cytokine staining was then performed in the dark on ice for $40 \mathrm{~min}$. The stained samples were then washed twice with FACS buffer and fixed with $0.5 \%$ PFA. For each sample, $1 \times 10^{6}$ events were acquired on a BD LSRII Fortessa, and data were analyzed using Flowjo software V10.

\subsection{ELISAS}

Vaccine antigen-specific IgG from mouse serum samples was measured by ELISA. Briefly, $2 \mu \mathrm{g} / \mathrm{mL}$ of antigen was coated on Nunc Maxisorp ELISA plates and incubated at $4{ }^{\circ} \mathrm{C}$ overnight. Plates were blocked with $150 \mu \mathrm{L} /$ well of $5 \%$ KPL milk diluent solution concentrate (SeraCare, Milford, MA, USA) in PBS with $0.1 \%$ Tween20 (PBST) for $1 \mathrm{~h}$ at room temperature. Blocking buffer was removed and replaced with mouse serum samples serially diluted in blocking buffer before incubation at $37^{\circ} \mathrm{C}$ for $1 \mathrm{~h}$. Plates were washed thrice in water before adding $50 \mu \mathrm{L} /$ well of 1:2500 diluted goat anti-mouse HRP-conjugated secondary antibody (Sigma Aldrich, St. Louis, MO, USA) in blocking buffer. Plates were incubated at $37^{\circ} \mathrm{C}$ for $1 \mathrm{~h}$ and washed as before prior to being developed for five minutes using $50 \mu \mathrm{L} /$ well of TMB chromogen solution (Life Technologies, Carlsbad, CA, USA). The substrate reactions were stopped by addition of $25 \mu \mathrm{L} /$ well of $1 \mathrm{M} \mathrm{H}_{2} \mathrm{SO}_{4}$ before reading the plate absorbance at $450 \mathrm{~nm}$. For IgG isotyping, ELISAs were performed as above, except goat anti-mouse isotype-specific secondary (anti-IgG1, -IgG2a, -IgG3, and -IgG2b; Sigma Aldrich) was applied at 1:2500 dilution in blocking buffer for $1 \mathrm{~h}$ at $37^{\circ} \mathrm{C}$. This was followed by washing thrice in water, adding HRP-conjugated rabbit anti-goat (Sigma Aldrich) diluted 1:2500 in blocking buffer, and incubating for $1 \mathrm{~h}$ at $37^{\circ} \mathrm{C}$. ELISA was then washed and revealed as previously described. Data was fit with one-site specific binding logarithm on Graphpad Prism 9. $\mathrm{EC}_{50}$ of sample against vaccine antigen is defined as the reciprocal of the serum dilution required to achieve binding of half of total antigen.

\subsection{Plaque Reduction Neutralisation Tests (PRNTs)}

To measure the neutralization capacity of the sera, PRNTs were performed. For influenza PRNTs, Nunc flat bottom tissue culture plates were seeded with $6 \times 10^{4}$ of Madin-Darby canine kidney cells (MDCKs) per well in DMEM (Gibco, Gaithersburg, MD, USA) supplemented with $10 \%$ heat-inactivated FCS followed by incubation overnight at $37{ }^{\circ} \mathrm{C}$ with $5 \% \mathrm{CO}_{2}$. Mouse serum samples were treated with receptor-destroying enzyme (RDE) (RDE[II]; Denka Seiken Co., Tokyo, Japan) at a ratio of 1 part serum to 3 parts RDE. Samples were incubated overnight at $37^{\circ} \mathrm{C}$ before heat inactivation at $56{ }^{\circ} \mathrm{C}$ for $30 \mathrm{~min}$. Treated serum samples were serially diluted before incubation for $1 \mathrm{~h}$ at $37^{\circ} \mathrm{C}$ with $5 \% \mathrm{CO}_{2}$ with 100 PFU/well of influenza virus (A/Auckland/1/2009 (H1N1)) in DMEM containing $4 \mu \mathrm{g} / \mathrm{mL}$ of TPCK-treated trypsin. Virus-serum mixtures were then added to MDCK cells and incubated for $1 \mathrm{~h}$ at $37^{\circ} \mathrm{C}$ with $5 \% \mathrm{CO}_{2}$. Virus-serum mixtures were discarded before adding $100 \mu \mathrm{L} /$ well of overlay (M199 media (Gibco) consisting of 2\% heat-inactivated FCS supplemented with penicillin-streptomycin and $1.5 \%$ medium viscosity carboxymethyl cellulose (CMC)) followed by 3 days of incubation at $37{ }^{\circ} \mathrm{C}$ with $5 \% \mathrm{CO}_{2}$. Plates were fixed in $80 \%$ acetone $/ 20 \%$ PBS for $20 \mathrm{~min}$ at $-20{ }^{\circ} \mathrm{C}$ before blocking in $5 \% \mathrm{KPL}$ milk diluent solution concentrate (SeraCare) in PBST for $1 \mathrm{~h}$ at room temperature. Plates were then stained with $2 \mu \mathrm{g} / \mathrm{mL}$ of anti-HA hFI6V3 monoclonal antibody $(\mathrm{mAb})$ for $1 \mathrm{~h}$ at $37^{\circ} \mathrm{C}$. Plates were washed three times in PBST before adding anti-human IR800 (Millennium Science, Mulgrave, Australia) diluted to 1:2500 in blocking buffer. The washing step was repeated, and plaques were revealed by scanning plates on an Odyssey CLX infrared imaging system (LI-COR). Plaques were counted and plotted on Graphpad Prism 9 using a 3-parameter $\log$ (inhibitor) vs. response model.

For RSV PRNTs, Nunc flat bottom tissue culture plates were seeded with $5 \times 10^{4}$ Vero cells/well in OptiMEM (Gibco) supplemented with 3\% heat-inactivated FCS and incubated overnight at $37{ }^{\circ} \mathrm{C}$ with $5 \% \mathrm{CO}_{2}$. Heat-inactivated serum samples were serially diluted 
in serum-free OptiMEM before the addition of RSV A2 virus (produced in Vero76 cells) diluted to $75 \mathrm{PFU} /$ well in OptiMEM. Virus-serum mixtures were incubated for $1 \mathrm{~h}$ at $37{ }^{\circ} \mathrm{C}$ with $5 \% \mathrm{CO}_{2}$ before adsorption onto plated cells for an additional hour at $37^{\circ} \mathrm{C}$ with $5 \% \mathrm{CO}_{2}$. Then, $100 \mu \mathrm{L} /$ well of virus overlay was added to all wells before incubation for 3 days at $37{ }^{\circ} \mathrm{C}$ with $5 \% \mathrm{CO}_{2}$. Plates were fixed and stained with anti-RSV $\mathrm{F}$ human motavizumab $(1 \mu \mathrm{g} / \mathrm{mL}) \mathrm{mAb}$ as described for influenza PRNTs. Plaques were counted and plotted on Graphpad Prism 9 using a 3-parameter $\log$ (inhibitor) vs. response model.

\subsection{Statistics}

Statistical analyses to generate $p$-values were conducted in GraphPad Prism 9 using an ANOVA test adjusted for multiple comparisons using Tukey's method on T-cell values and transformed $\log$ values of $\mathrm{EC}_{50} \mathrm{~s}$ and $\mathrm{IC}_{50} \mathrm{~s}$.

\section{Results}

\subsection{Humoral Responses}

To determine which adjuvant is best suited for our candidate prefusion antigens, an immunization study was performed using a panel of adjuvants analogous to formulations that are currently approved in humans or in clinical development (Figure 1A). After two immunizations of HA clamp, we observed that inclusion of any adjuvant increased humoral immunity significantly beyond placebo (PBS) and antigen only (Figure 1B). Mice immunized with HA clamp with Addavax elicited the highest total IgG in comparison to all groups (Figure 1B). Despite these differences between total IgG, sera from all adjuvanted groups were able to neutralize homologous influenza virus to a similar extent, with ALF55 eliciting the highest neutralization, reaching a statistical significance only in comparison to the QS21 group (Figure 1C).

In contrast to the HA clamp results, two immunizations with RSV F clamp with either alhydrogel or AdQS21 elicited the highest IgG response, with significant differences observed when comparing alhydrogel to QS21 and Addavax (Figure 1B). Notably, the AdQS21 group elicited significantly higher IgG EC 50 in comparison to its constituents alone (QS21 and Addavax groups). Following analysis of virus-neutralizing antibody response, all the adjuvanted groups elicited a neutralizing antibody response that was higher than the antigen only and placebo groups in the RSV F clamp study (Figure 1C). However, this was only statistically significant for the alhydrogel, AdQS21, and ALF55 groups (Figure 1C). A general trend was observed for both F clamp and HA clamp immunizations, where higher IgG responses correlated with higher neutralization (Figure 1D; $r^{2}=0.39, p<0.001$ for F clamp; $r^{2}=0.18, p=0.02$ for HA clamp). This was exemplified by RSV F clamp adjuvant groups, where the lower IgG response from the QS21 group was associated with lower neutralization capacity of RSV, and the significantly higher IgG response from the alhydrogel group was associated with higher $\mathrm{IC}_{50}$.

Both neutralizing and non-neutralizing antibodies have been implicated in protection against influenza and RSV infection [43-48]. Non-neutralizing antibodies may offer protection through Fc-mediated effector functions, such as the killing of infected cells by antibody-dependent cellular cytotoxicity (ADCC). ADCC has been implicated in both influenza and RSV infection and vaccination [46,49-54]. In the murine model, ADCC is mediated by IgG2a and IgG2b isotypes [55]. As such, to further investigate the quality of response elicited by each adjuvant, sera were isotyped into IgG1, IgG2a, IgG2b, and IgG3 subclasses (Figure 2, Supplementary Materials Table S1). For HA clamp, a robust IgG1 response was observed for all adjuvants (Figure 2A). For RSV F clamp, QS21 had the lowest IgG1 $\mathrm{EC}_{50}$ in comparison to all other adjuvanted groups, yet this only reached statistical significance for alhydrogel and AdQS21 (Figure 2A). Additionally, AdQS21 elicited a significantly higher level of IgG1 when compared to ALF55 (Figure 2A). 
A
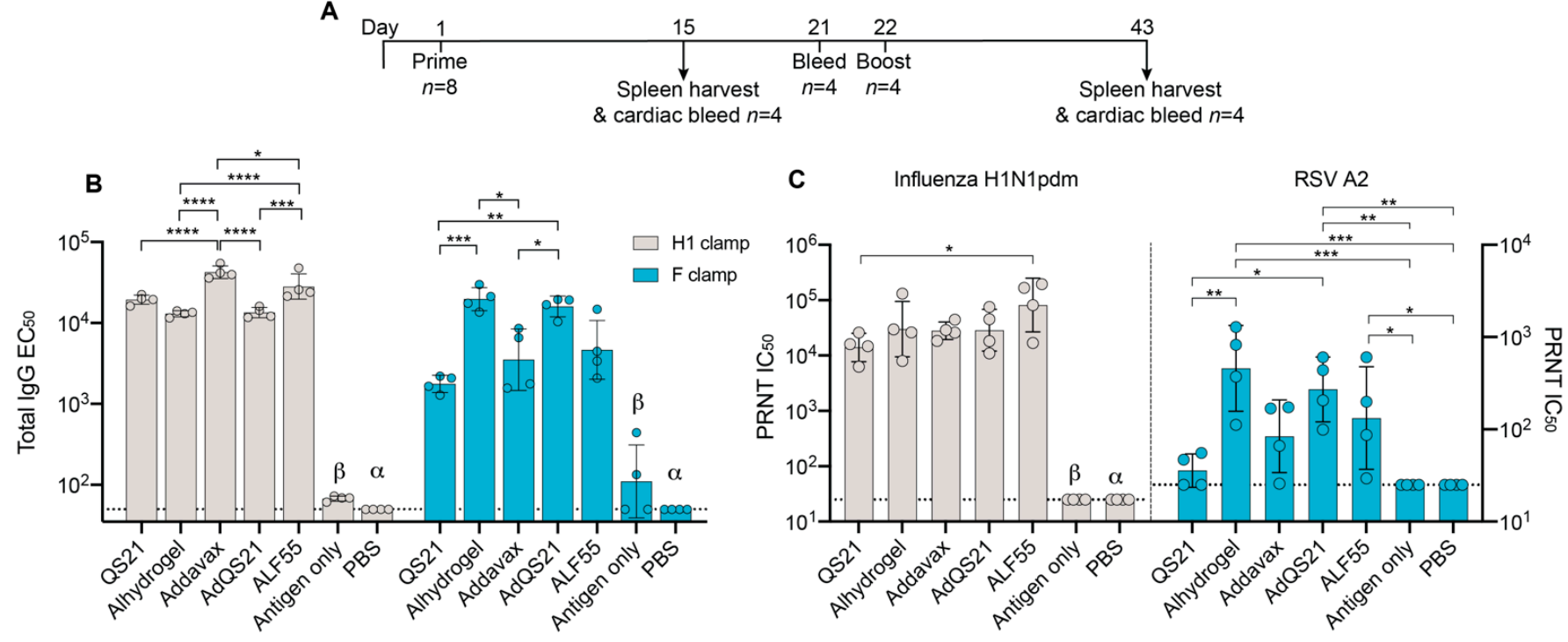

D

RSV F clamp
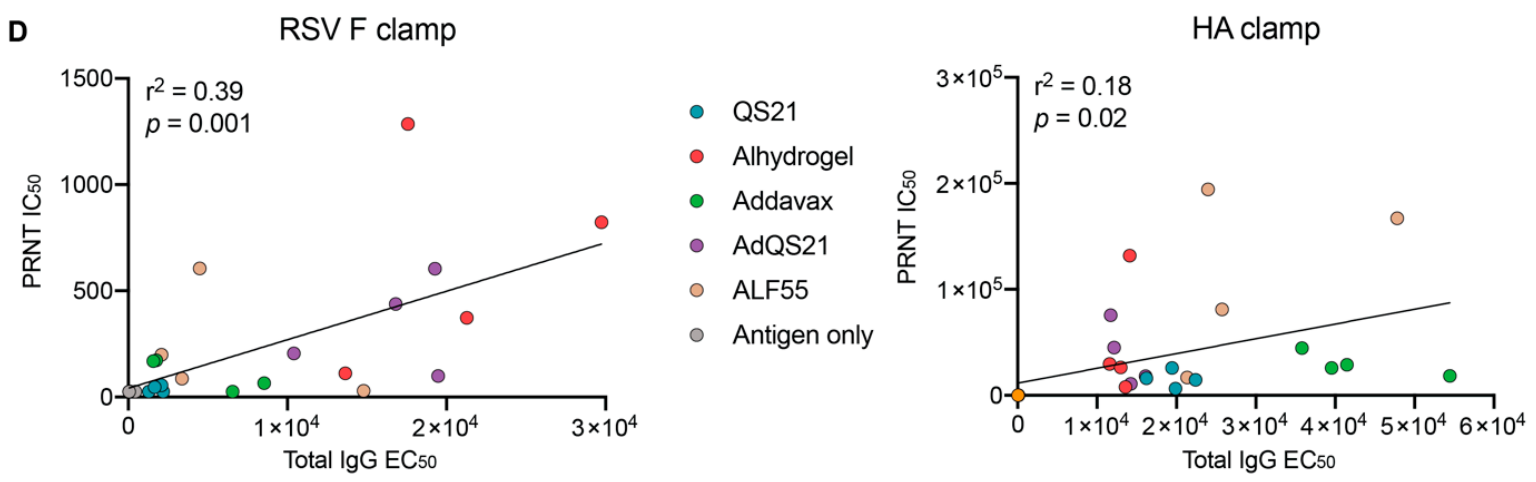

Figure 1. Serum analysis of terminal bleed from mice immunized with clamped antigen with different adjuvants. (A) Schematic of immunization regime. (B) ELISA EC 50 of serum against each vaccine antigen on day 43 . Dotted line shows limit of detection. (C) Serum samples from final cardiac bleed (day 43) tested against homologous H1N1pdm (A/Auckland/1/2009, left) virus or respiratory syncytial virus (RSV) A2 (right) in a plaque reduction neutralization test (PRNT). Data represents geometric mean $(n=4)$ with geometric standard deviation (SD). Dotted line shows limit of detection. $p$-values were calculated using a one-way Tukey's multiple comparison ANOVA, where* indicates $p<0.05, * * p<0.005$, *** $p<0.0005$, and ${ }^{* * * *} p<0.0001 ; \beta=p<0.0001$ compared to all groups except PBS, and $\alpha=p<0.0001$ compared to all groups unless otherwise specified. (D) Linear regressions of PRNT IC ${ }_{50}$ vs. total IgG $\mathrm{EC}_{50}$ from groups vaccinated with RSV fusion (F) clamp (left) and haemagglutinin (HA) clamp (right).

IgG2a responses in the mouse model have been previously shown to play a significant role in the outcomes of viral infections, and its production is upregulated by IFN- $\gamma$ [55]. Generation of IgG2a isotype strengthens pathogen clearance as it is associated with stronger Fc $\gamma$ R-mediated activity, allowing for activation of ADCC [55]. In the HA clamp vaccination, alhydrogel was seen to elicit a significantly lower IgG2a response in comparison to all adjuvant groups (Figure 2B). In the RSV F clamp study, AdQS21 elicited an IgG2a response that was significantly higher than its constituents alone (Addavax and QS21) (Figure 2B). Interestingly, this was not recapitulated in the HA clamp study, where QS21 and Addavax elicited significantly higher IgG2a levels in comparison to AdQS21 (Figure 2B). IgG2b stimulates Fc $\gamma R$ functions and typically arises early in the humoral response through a T-independent pathway [55]. The IgG2b response between adjuvant groups displayed similarities to the IgG2a pattern for both HA clamp and RSV F clamp (Figure 2C). Here, we observed that immunization with HA clamp with alhydrogel or AdQS21 displayed a decreased IgG2b response. In contrast, these adjuvant groups were the top responders in the RSV F clamp immunizations (Figure 2C). IgG3, involved in complement fixation, 
was also elicited by all adjuvant groups, with a reduced response for QS21 and Addavax groups with RSV F clamp immunization (Figure 2D). We observed that for the RSV F clamp study, AdQS21 elicited the highest levels of all isotypes.

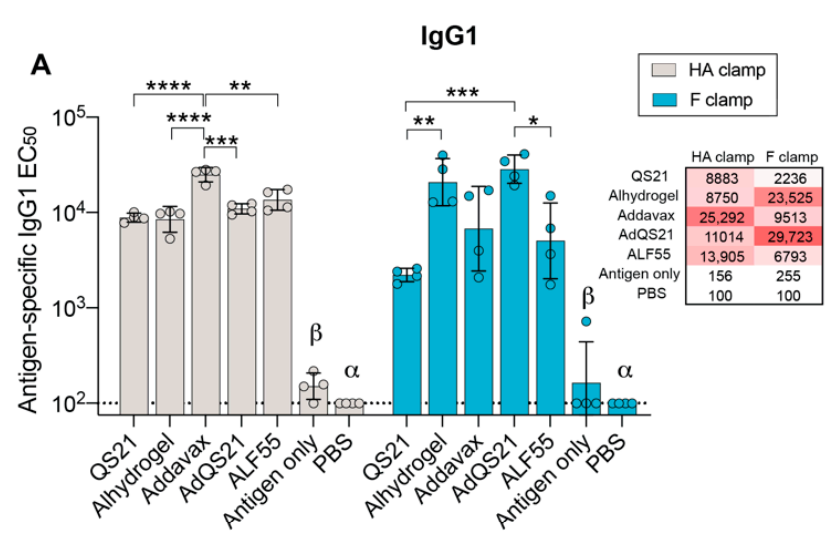

C

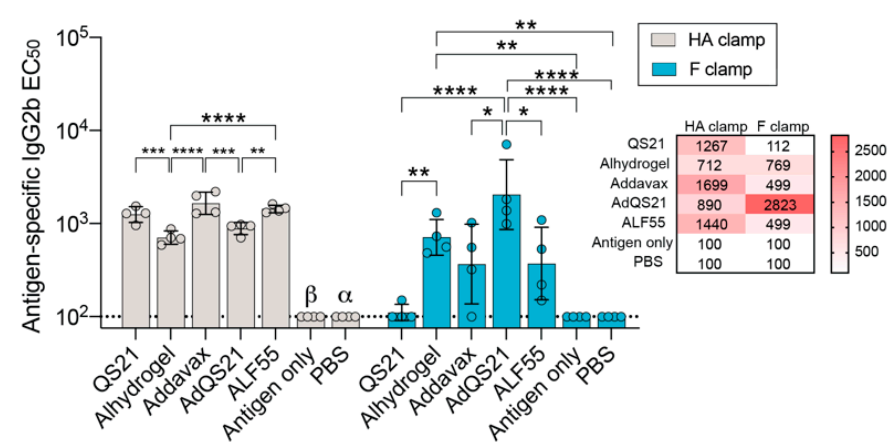

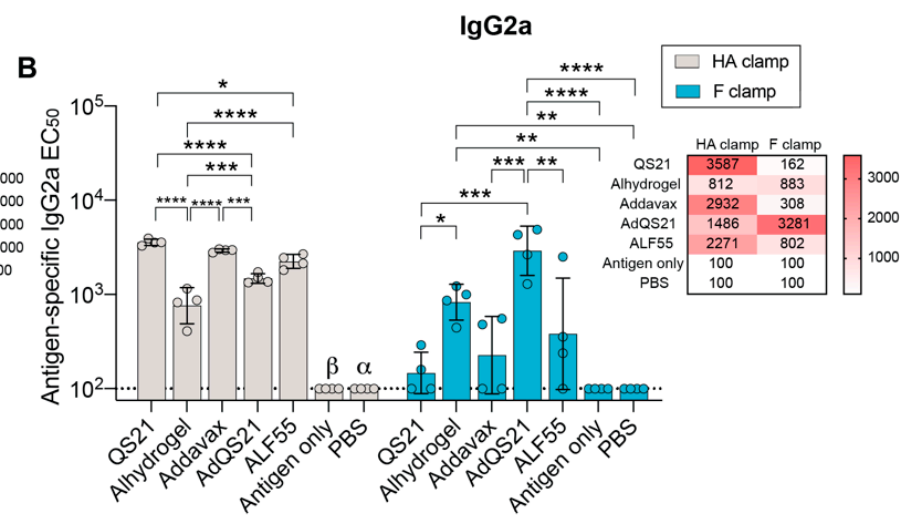

D

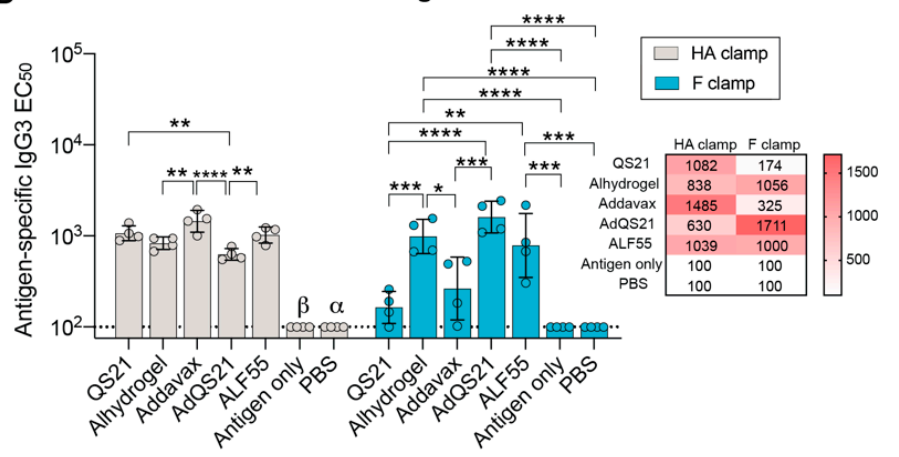

Figure 2. Antibody isotyping of mouse sera post antigen immunization with various adjuvants. Data shown is from the final terminal bleed. Sera from individual mice $(n=4)$ were isotyped by ELISA against the vaccine antigen with secondary antibodies specific for mouse IgG1 (A), IgG2a (B), IgG2b (C), and IgG3 (D) with PBS background subtracted. Data represents geometric mean with geometric SD. Dotted line shows limit of detection. A heat map is shown for each isotype, with values representing means of each group. Statistics calculated using a one-way Tukey's multiple comparison ANOVA, where * indicates a $p<0.05,{ }^{* *} p<0.005,{ }^{* * *} p<0.0005$, and ${ }^{* * * *} p<0.0001 ; \beta=p<0.0005$ compared to all groups except PBS, and $\alpha=$ $p<0.0001$ compared to all groups unless otherwise specified.

\subsection{T-Cell Responses}

We next aimed to measure the T-cell responses elicited by immunization with our HA clamp vaccine candidate. Here, $\mathrm{CD}^{+}$and $\mathrm{CD} 8^{+} \mathrm{T}$-cells were analyzed for the production of IL- 2 and antiviral cytokines IFN- $\gamma$ and tumor necrosis factor (TNF) $-\alpha$ to delineate antigenspecific T cell subsets (Figure 3, Supplementary Materials Table S2). In this analysis, we observed that immunization of HA clamp with QS21 or alhydrogel elicited a significantly higher percentage of $\mathrm{CD} 4^{+} \mathrm{IFN}-\gamma^{+}$cells in comparison to PBS, yet none of the adjuvants significantly increased the frequency of $\mathrm{CD} 4^{+} \mathrm{IFN}-\gamma^{+}$cells in comparison to antigen alone (Figure 3). Moreover, with the exception of ALF55, alhydrogel elicited a markedly reduced percentage of $\mathrm{CD}^{+}$IFN- $\gamma^{+}$cells in comparison to all adjuvants. We also observed that none of the adjuvants were able to significantly increase the frequency of $\mathrm{CD} 8^{+} \mathrm{IFN}-\gamma^{+}$ cells in comparison to antigen alone.

Despite its usage as a parameter to measure vaccine-specific T-cell immunity, induction of IFN- $\gamma$ alone or its magnitude does not correlate with effective protective immunity [42]. However, induction of IL-2 has been shown to be required for the maintenance of memory T-cells [56-58]. Strikingly, our results show that upon HA clamp immunization, alhydrogel elicited a significantly elevated $\mathrm{CD} 4^{+}$and $\mathrm{CD} 8^{+} \mathrm{IL}-2^{+}$response in comparison to all other 
groups tested (Figure 3). Finally, no significant differences in either $\mathrm{CD} 4^{+}$and $\mathrm{CD} 8^{+} \mathrm{TNF} \alpha^{+}$ cells were observed between any of the adjuvant groups and PBS (Figure 3).
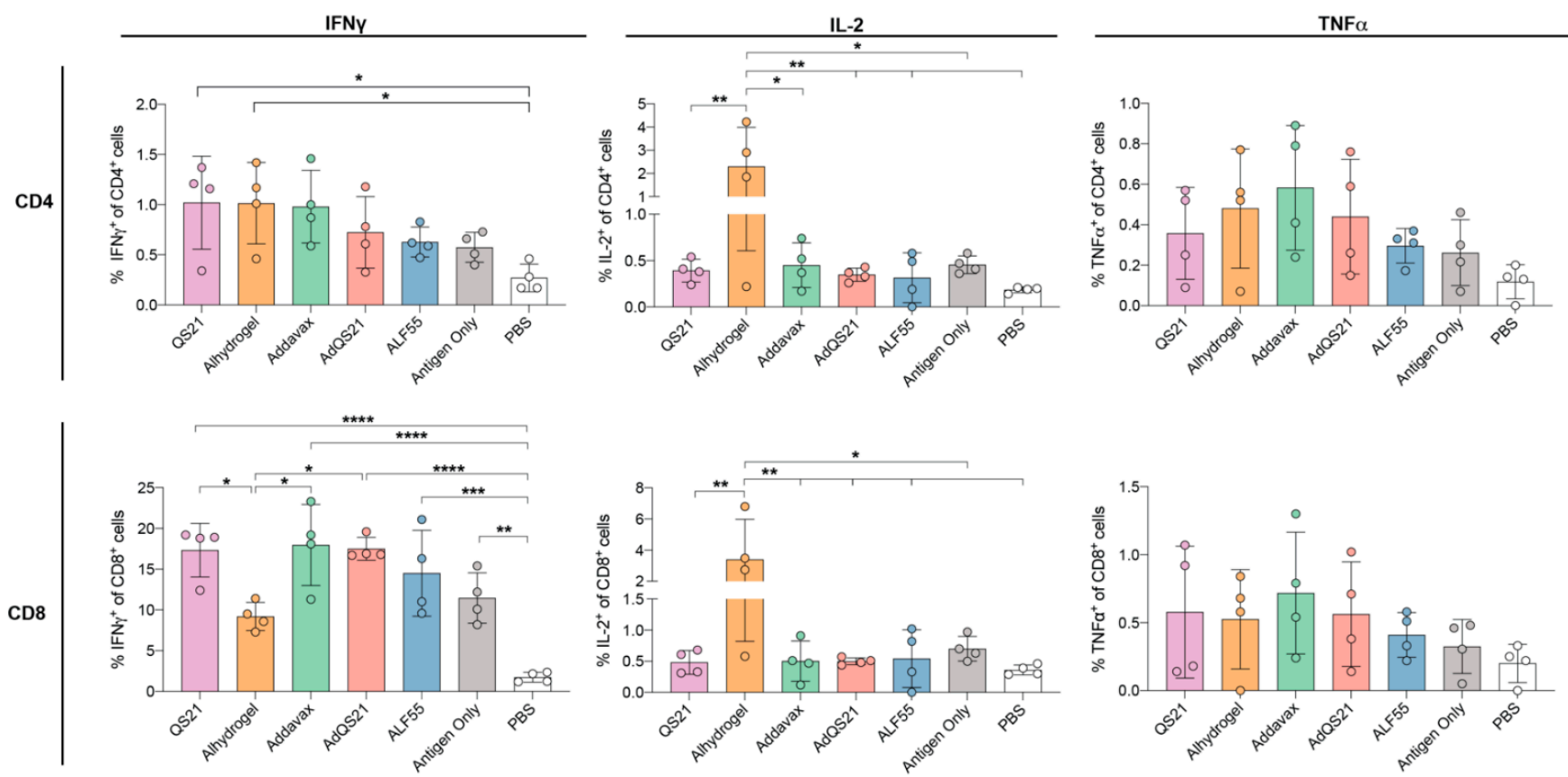

Figure 3. $\mathrm{CD}^{+}$and $\mathrm{CD} 8^{+} \mathrm{T}$-cell cytokine profiling of mice immunized with HA clamp alongside various adjuvants. Data shown is from day 43 spleen harvest. Data shown is after subtraction of PBS-stimulated cells. Data represents mean $(n=4)$ with SD. Statistics calculated using a one-way Tukey's multiple comparison ANOVA, where * indicates a $p<0.05$, ${ }^{* *} p<0.005,{ }^{* * *} p<0.0005$, and ${ }^{* * * *} p<0.0001$.

\section{Discussion}

The aim of this study was to determine if a single adjuvant formulation could be used for various clamp-stabilized subunit vaccines. To assess this, we tested the humoral response of the adjuvant panel co-administered with previously developed prefusionstabilized clamped RSV F or influenza HA. Utilizing this approach, we aimed to elicit prefusion-reactive, conformationally dependent antibodies, which have been shown to be protective for both RSV and influenza [40,41]. Interestingly, we found that formulation of the same adjuvant with different antigens elicited differential humoral responses in terms of total IgG and virus neutralization. This was exemplified by adjuvants like QS21 and Addavax, which elicited high levels of total IgG and neutralized virus efficiently for HA clamp yet did not neutralize RSV above the levels for placebo or antigen alone in the RSV F clamp study (Figure 1). This could in part be a result of different adsorption capacities of antigen to adjuvant, which can be dependent on intrinsic protein properties and can influence stability and biological activity. This is consistent with previous reports of antigen-dependent adsorption on aluminum salts [59-61], emulsions [62-64], and lipid vesicles [64-66]. Furthermore, it has been reported that formulation with certain adjuvants may affect protein structure and stability, which is in part dependent on adjuvant-antigen interactions, with downstream biological consequences in vaccinations $[64,67,68]$. Moreover, antigens alone may possess immune-stimulatory effects. Indeed, while viral nucleic acids are the prototypical pathogen-associated molecular patterns (PAMPs), which are recognized by pathogen recognition receptors such as TLRs, there have been several reports of viral protein antigens acting as PAMPs. This has been demonstrated for RSV F, influenza $\mathrm{HA}$, and dengue nonstructural protein 1 (NS1), all of which have been shown to activate TLR4 [69-72], as well as measles virus HA, which has been shown to activate TLR2 [73]. Therefore, we suggest that both absorption capacity and the intrinsic immune-stimulatory effects of antigens may play a role in adjuvant-antigen interactions. This highlights that 
the adjuvants most suited for pairing purposes can vary depending on the antigen used and/or on the desired immune response.

In the RSV study, we observed a significant positive correlation between antigenspecific total antibody responses and neutralization capacity (Figure 1D). This was exemplified in the alhydrogel, AdQS21, and ALF55 adjuvant groups, where high humoral responses correlated with high neutralization capacities, indicating that these adjuvants elicit potent, favorable humoral responses. Interestingly, the two adjuvant groups that elicited the most potent neutralization (alhydrogel and AdQS21) also elicited the highest amount of the IgG1 isotype (Figure 2A). This is consistent with the primary function of IgG1 in the murine model, which is to neutralize virus through steric hinderance [55]. Other protective functions, such as ADCC, have been deemed important in protection from RSV infection and are mediated by IgG2a and IgG2b isotypes in the murine model $[46,52,55]$. We found that AdQS21 elicited the highest levels of all isotypes, particularly IgG2a and $\operatorname{IgG} 2 b$, indicating a well-rounded response (Figure 2). High levels of antigen-specific IgG2a and IgG2b isotype may indicate Fc-mediated effector functions and may contribute to enhanced protection against RSV in vivo [46]. This has been reported in the context of immunotherapy with palivizumab, where it was shown that a human IgG1 isotype (mouse IgG2a homolog) was able to reduce viral titres in lungs of cotton rats to a greater extent in comparison to their human IgG2 counterpart [46,74]. Despite this, the effects of isotypes elicited from immunization on Fc-mediated functions against RSV remains to be investigated.

In comparison to RSV, the positive correlation between antigen-specific antibodies and virus neutralization in the HA study was more subtle but still reached statistical significance (Figure 1D). This trend could be confounded by the presence of non-neutralizing HA stem-specific antibodies, which can be elicited upon vaccination with prefusion HA antigens $[75,76]$. Non-neutralizing, stem-specific antibodies are typically cross-reactive between influenza subtypes and may offer protection against infection through ADCC [43,76]. We found that all adjuvants were able to elicit IgG2a and IgG2b antibodies above antigen only vaccination, with QS21 eliciting the highest level of IgG2a (Figure 2). This is a favorable response as high levels of HA-specific IgG2a could contribute to increased protection, as previously reported in murine influenza protection studies $[43,77,78]$.

In the HA clamp study, we observed that none of the adjuvants were able to improve production of vaccine-specific IFN- $\gamma$ and TNF- $\alpha$ by CD $4^{+}$and $C D 8^{+}$T-cells in comparison to antigen alone; however, longer splenocyte peptide stimulation may result in more effective recall. This was consistent with what has been observed with other adjuvanted viral subunit vaccines $[79,80]$. However, alhydrogel was able to elicit relatively elevated vaccine-specific IL-2 in both $\mathrm{CD} 4^{+}$and $\mathrm{CD} 8^{+} \mathrm{T}$ cells subsets. While IL-2 has no direct antiviral activity, it is known to help maintain expansion and proliferation of antigen-specific T-cells, ensuring longevity and the ability of these cells to establish immunological memory [81,82]. This has been observed in HIV-specific CD4 ${ }^{+}$T-cells [82-84], specifically those associated with mucosal protection [56]. More pertinently, IL-2 has also been implicated in the expansion of $\mathrm{CD} 8^{+} \mathrm{T}$-cells upon influenza infection and as such may be an important contributor to cellular immunity against infection [85-91]. If required, other approaches may be used to further enhance cellular immunity against HA, such as employing different prime-boost regimens, nanoparticle presentation, additional viral protein targets, or vectored strategies $[57,92,93]$.

\section{Conclusions}

In summary, this work serves as a pilot study to demonstrate the ability of our vaccine strategy to induce effective humoral and cellular immune responses in the BALB/c model with different adjuvant-antigen pairings. We observed robust humoral immune responses for all adjuvants paired with HA clamp and for alhydrogel, AdQS21, and ALF55 groups paired with RSV F clamp. This study has highlighted the importance of adjuvant selection for different antigens, where the same adjuvant may elicit varying immune responses 
based on the antigen it is formulated with. We suggest that this could be in part due to different adsorption rates of antigen to adjuvant as well as intrinsic immune stimulatory effects of antigens alone that may work in synergism or hinder adjuvant effects. This is highlighted in the isotyping data, where AdQS21 elicited a well-rounded response for all isotypes when formulated with RSV F clamp; however, this was not reproduced in the HA clamp study. As such, we conclude that an adjuvant trial for different subunit vaccines in development would likely be necessary, with a necessity to conduct formulation work, particularly if the vaccine candidate was to progress into a challenge model or human clinical trials.

Supplementary Materials: The following are available online at https:/ /www.mdpi.com/2076-393 $\mathrm{X} / 9 / 2 / 71 / \mathrm{s} 1$.

Author Contributions: Conceptualization, K.J.C., C.R., and D.W.; methodology, K.J.C., D.W., C.R., Z.L., and A.I.; investigation, A.I., S.T.M.C., and Z.L.; formal analysis, A.I. and Z.L.; visualization, A.I., Z.L., and D.K.W.; resources, N.M. and C.L.D.M.; writing-original draft preparation, A.I.; writing-review and editing, K.J.C., D.W., D.K.W., C.R., Z.L., N.M., C.L.D.M., and P.R.Y.; supervision, P.R.Y., K.J.C., and D.W. All authors have read and agreed to the published version of the manuscript.

Funding: This research was funded by NHMRC Project grant APP1144025, NHMRC Development grant APP1125107 and the Coalition for Epidemic Preparedness and Innovations.

Institutional Review Board Statement: The study was conducted according to the guidelines of the Declaration of Helsinki, and approved by the Institutional Review Board (or Ethics Committee) of the University of Queensland Animal Ethics Unit (SCMB/558/17, 27 Feb 2018).

Data Availability Statement: The data presented in this study are available within the article and supplementary material.

Conflicts of Interest: K.J.C., D.W., and P.R.Y. are inventors of the "Molecular Clamp" patent, US 2020/0040042.

\section{References}

1. Krammer, F. SARS-CoV-2 vaccines in development. Nature 2020, 586, 516-527. [CrossRef] [PubMed]

2. Moyle, P.M.; Toth, I. Modern Subunit Vaccines: Development, Components, and Research Opportunities. Chem. Med. Chem. 2013, 8, 360-376. [CrossRef] [PubMed]

3. George, P.J.; Tai, W.; Du, L.; Lustigman, S. The Potency of an Anti-MERS Coronavirus Subunit Vaccine Depends on a Unique Combinatorial Adjuvant Formulation. Vaccines 2020, 8, 251. [CrossRef] [PubMed]

4. Del Giudice, G.; Rappuoli, R.; Didierlaurent, A.M. Correlates of adjuvanticity: A review on adjuvants in licensed vaccines. Semin. Immunol. 2018, 39, 14-21. [CrossRef] [PubMed]

5. Knudsen, N.P.H.; Olsen, A.; Buonsanti, C.; Follmann, F.; Zhang, Y.; Coler, R.N.; Fox, C.B.; Meinke, A.; D’OOro, U.; Casini, D.; et al. Different human vaccine adjuvants promote distinct antigen-independent immunological signatures tailored to different pathogens. Sci. Rep. 2016, 6, 19570. [CrossRef]

6. Reed, S.G.; Orr, M.T.; Fox, C.B. Key roles of adjuvants in modern vaccines. Nat. Med. 2013, 19, 1597-1608. [CrossRef]

7. Younis, S.Y.; Barnier-Quer, C.; Heuking, S.; Sommandas, V.; Brunner, L.; Vd.Werff, N.; Dubois, P.; Friede, M.; Kocken, C.; Collin, N.; et al. Down selecting adjuvanted vaccine formulations: A comparative method for harmonized evaluation. BMC Immunol. 2018, 19, 6. [CrossRef]

8. Hawken, J.; Troy, S.B. Adjuvants and inactivated polio vaccine: A systematic review. Vaccine 2012, 30, 6971-6979. [CrossRef]

9. De Gregorio, E.; Tritto, E.; Rappuoli, R. Alum adjuvanticity: Unraveling a century old mystery. Eur. J. Immunol. 2008, 38, 2068-2071. [CrossRef]

10. Gupta, R.K. Aluminum compounds as vaccine adjuvants. Adv. Drug Deliv. Rev. 1998, 32, 155-172. [CrossRef]

11. Brewer, J.M. (How) do aluminium adjuvants work? Immunol. Lett. 2006, 102, 10-15. [CrossRef] [PubMed]

12. Oleszycka, E.; Lavelle, E.C. Immunomodulatory properties of the vaccine adjuvant alum. Curr. Opin. Immunol. 2014, 28, 1-5. [CrossRef] [PubMed]

13. Mori, A.; Oleszycka, E.; Sharp, F.A.; Coleman, M.; Ozasa, Y.; Singh, M.; O’Hagan, D.T.; Tajber, L.; Corrigan, O.I.; McNeela, E.A.; et al. The vaccine adjuvant alum inhibits IL-12 by promoting PI3 kinase signaling while chitosan does not inhibit IL-12 and enhances Th1 and Th17 responses. Eur. J. Immunol. 2012, 42, 2709-2719. [CrossRef] [PubMed]

14. Didierlaurent, A.M.; Morel, S.; Lockman, L.; Giannini, S.L.; Bisteau, M.; Carlsen, H.; Kielland, A.; Vosters, O.; Vanderheyde, N.; Schiavetti, F.; et al. AS04, an Aluminum Salt- and TLR4 Agonist-Based Adjuvant System, Induces a Transient Localized Innate Immune Response Leading to Enhanced Adaptive Immunity. J. Immunol. 2009, 183, 6186. [CrossRef] 
15. Casella, C.R.; Mitchell, T.C. Putting endotoxin to work for us: Monophosphoryl lipid A as a safe and effective vaccine adjuvant. Cell Mol. Life Sci. 2008, 65, 3231. [CrossRef]

16. Baldridge, J.R.; McGowan, P.; Evans, J.T.; Cluff, C.; Mossman, S.; Johnson, D.; Persing, D. Taking a Toll on human disease: Toll-like receptor 4 agonists as vaccine adjuvants and monotherapeutic agents. Expert Opin. Biol. Ther. 2004, 4, 1129-1138. [CrossRef]

17. Garcon, N.; Chomez, P.; Van Mechelen, M. GlaxoSmithKline Adjuvant Systems in vaccines: Concepts, achievements and perspectives. Expert Rev. Vaccines 2007, 6, 723-739. [CrossRef]

18. Didierlaurent, A.M.; Laupèze, B.; Di Pasquale, A.; Hergli, N.; Collignon, C.; Garçon, N. Adjuvant system AS01: Helping to overcome the challenges of modern vaccines. Expert Rev. Vaccines 2017, 16, 55-63. [CrossRef]

19. Coccia, M.; Collignon, C.; Hervé, C.; Chalon, A.; Welsby, I.; Detienne, S.; van Helden, M.J.; Dutta, S.; Genito, C.J.; Waters, N.C.; et al. Cellular and molecular synergy in AS01-adjuvanted vaccines results in an early IFN $\gamma$ response promoting vaccine immunogenicity. NPJ Vaccines 2017, 2, 25. [CrossRef]

20. Garçon, N.; Di Pasquale, A. From discovery to licensure, the Adjuvant System story. Hum. Vaccines Immunother. 2017, 13, 19-33. [CrossRef]

21. Garçon, N.; Vaughn, D.W.; Didierlaurent, A.M. Development and evaluation of AS03, an Adjuvant System containing $\alpha-$ tocopherol and squalene in an oil-in-water emulsion. Expert Rev. Vaccines 2012, 11, 349-366. [CrossRef] [PubMed]

22. O'Hagan, D.T.; Ott, G.S.; Nest, G.V.; Rappuoli, R.; Giudice, G.D. The history of MF59((R)) adjuvant: A phoenix that arose from the ashes. Expert Rev. Vaccines 2013, 12, 13-30. [CrossRef] [PubMed]

23. O'Hagan, D.T. MF59 is a safe and potent vaccine adjuvant that enhances protection against influenza virus infection. Expert Rev. Vaccines 2007, 6, 699-710. [CrossRef] [PubMed]

24. Schultze, V.; D’Agosto, V.; Wack, A.; Novicki, D.; Zorn, J.; Hennig, R. Safety of MF59 ${ }^{\mathrm{TM}}$ adjuvant. Vaccine 2008, 26, 3209-3222. [CrossRef] [PubMed]

25. Chappell, K.J.; Watterson, D.; Young, P.R. Chimeric Molecules and Uses Thereof 2018.

26. Osterholm, M.T.; Kelley, N.S.; Sommer, A.; Belongia, E.A. Efficacy and effectiveness of influenza vaccines: A systematic review and meta-analysis. Lancet. Infect. Dis. 2012, 12, 36-44. [CrossRef]

27. Mameli, C.; D’auria, E.; Erba, P.; Nannini, P.; Zuccotti, G.V. Influenza vaccine response: Future perspectives. Expert Opin. Biol. Ther. 2018, 18, 1-5. [CrossRef]

28. Kumar, A.; Meldgaard, T.S.; Bertholet, S. Novel Platforms for the Development of a Universal Influenza Vaccine. Front. Immunol. 2018, 9, 600. [CrossRef]

29. Gross, P.A.; Ennis, F.A.; Gaerlan, P.F.; Denson, L.J.; Denning, C.R.; Schiffman, D. A controlled double-blind comparison of reactogenicity, immunogenicity, and protective efficacy of whole-virus and split-product influenza vaccines in children. J. Infect. Dis. 1977, 136, 623-632. [CrossRef]

30. Wong, S.-S.; Webby, R.J. Traditional and new influenza vaccines. Clin. Microbiol. Rev. 2013, 26, 476-492. [CrossRef]

31. Acosta, P.L.; Caballero, M.T.; Polack, F.P. Brief History and Characterization of Enhanced Respiratory Syncytial Virus Disease. Clin. Vaccine Immunol. 2016, 23, 189. [CrossRef]

32. Murphy, B.R.; Walsh, E.E. Formalin-inactivated respiratory syncytial virus vaccine induces antibodies to the fusion glycoprotein that are deficient in fusion-inhibiting activity. J. Clin. Microbiol. 1988, 26, 1595-1597. [CrossRef] [PubMed]

33. ClinicalTrials.gov. A Study to Test GlaxoSmithKline's (GSK) Respiratory Syncytial Virus RSV Candidate Vaccine's Safety and Immune Response in Japanese Older Adults. Available online: https://clinicaltrials.gov/ct2/show/NCT04090658 (accessed on 15 December 2020).

34. ClinicalTrials.gov. Study of Safety, Reactogenicity and Immunogenicity of GlaxoSmithKline's (GSK)Respiratory Syncytial Virus (RSV)Maternal Unadjuvanted Vaccine in Healthy Pregnant Women (Aged 18 to 40 Years) and Their Infants. Available online: https: / / clinicaltrials.gov/ct2/show / NCT04126213 (accessed on 15 December 2020).

35. ClinicalTrials.gov. Dose, Safety, Tolerability and Immunogenicity of a Stabilized Prefusion RSV F Subunit Protein Vaccine, VRC-RSVRGP084-00-VP (DS-Cav1), Alone or With Alum Adjuvant, in Healthy Adults. Available online: https: / clinicaltrials. gov/ct2/show/NCT03049488 (accessed on 15 December 2020).

36. ClinicalTrials.gov. A Study of an Ad26.RSV.preF-based Regimen in the Prevention of Reverse Transcriptase Polymerase Chain Reaction (RT-PCR)-Confirmed Respiratory Syncytial Virus (RSV)-Mediated Lower Respiratory Tract Disease in Adults Aged 65 Years and Older. Available online: https:/ / clinicaltrials.gov/ct2/show/NCT03982199 (accessed on 15 December 2020).

37. ClinicalTrials.gov. Evaluating the Infectivity, Safety, and Immunogenicity of a Recombinant Live-Attenuated Respiratory Syncytial Virus Vaccine in RSV-Seronegative Infants and Children 6 to 24 Months of Age. Available online: https:/ / clinicaltrials.gov / ct2 / show / NCT02952339 (accessed on 15 December 2020).

38. Wijesundara, D.K.; Avumegah, M.S.; Lackenby, J.; Modhiran, N.; Isaacs, A.; Young, P.R.; Watterson, D.; Chappell, K.J. Rapid Response Subunit Vaccine Design in the Absence of Structural Information. Front. Immunol. 2020, 11, 592370. [CrossRef] [PubMed]

39. Watterson, D.; Wijesundara, D.; Modhiran, N.; Mordant, F.; Li, Z.; Avumegah, M.; McMillan, C.; Lackenby, J.; Guilfoyle, K.; van Amerongen, G.; et al. Molecular clamp stabilised Spike protein for protection against SARS-CoV-2. Res. Sq. Prepr. 2020. [CrossRef] 
40. Corti, D.; Voss, J.; Gamblin, S.J.; Codoni, G.; Macagno, A.; Jarrossay, D.; Vachieri, S.G.; Pinna, D.; Minola, A.; Vanzetta, F.; et al. A neutralizing antibody selected from plasma cells that binds to group 1 and group 2 influenza A hemagglutinins. Science 2011, 333, 850-856. [CrossRef] [PubMed]

41. Magro, M.; Mas, V.; Chappell, K.; Vázquez, M.; Cano, O.; Luque, D.; Terrón, M.C.; Melero, J.A.; Palomo, C. Neutralizing antibodies against the preactive form of respiratory syncytial virus fusion protein offer unique possibilities for clinical intervention. Proc. Natl. Acad. Sci. USA 2012, 109, 3089-3094. [CrossRef] [PubMed]

42. Ranasinghe, C.; Turner, S.J.; McArthur, C.; Sutherland, D.B.; Kim, J.H.; Doherty, P.C.; Ramshaw, I.A. Mucosal HIV-1 pox virus prime-boost immunization induces high-avidity CD8+ T cells with regime-dependent cytokine/granzyme B profiles. J. Immunol. 2007, 178, 2370-2379. [CrossRef]

43. DiLillo, D.J.; Tan, G.S.; Palese, P.; Ravetch, J.V. Broadly neutralizing hemagglutinin stalk-specific antibodies require Fc $\gamma$ R interactions for protection against influenza virus in vivo. Nat. Med. 2014, 20, 143-151. [CrossRef]

44. Jegaskanda, S.; Luke, C.; Hickman, H.D.; Sangster, M.Y.; Wieland-Alter, W.F.; McBride, J.M.; Yewdell, J.W.; Wright, P.F.; Treanor, J.; Rosenberger, C.M.; et al. Generation and Protective Ability of Influenza Virus-Specific Antibody-Dependent Cellular Cytotoxicity in Humans Elicited by Vaccination, Natural Infection, and Experimental Challenge. J. Infect. Dis. 2016, 214, 945-952. [CrossRef]

45. Jegerlehner, A.; Schmitz, N.; Storni, T.; Bachmann, M.F. Influenza A vaccine based on the extracellular domain of M2: Weak protection mediated via antibody-dependent NK cell activity. J. Immunol. 2004, 172, 5598-5605. [CrossRef]

46. Van Erp, E.A.; Luytjes, W.; Ferwerda, G.; van Kasteren, P.B. Fc-Mediated Antibody Effector Functions During Respiratory Syncytial Virus Infection and Disease. Front. Immunol. 2019, 178, 2370-2379. [CrossRef]

47. Wagner, D.K.; Muelenaer, P.; Henderson, F.W.; Snyder, M.H.; Reimer, C.B.; Walsh, E.E.; Anderson, L.J.; Nelson, D.L.; Murphy, B.R. Serum immunoglobulin $\mathrm{G}$ antibody subclass response to respiratory syncytial virus $\mathrm{F}$ and $\mathrm{G}$ glycoproteins after first, second, and third infections. J. Clin. Microbiol. 1989, 27, 589-592. [CrossRef] [PubMed]

48. Watanabe, A.; McCarthy, K.R.; Kuraoka, M.; Schmidt, A.G.; Adachi, Y.; Onodera, T.; Tonouchi, K.; Caradonna, T.M.; Bajic, G.; Song, S.; et al. Antibodies to a Conserved Influenza Head Interface Epitope Protect by an IgG Subtype-Dependent Mechanism. Cell 2019, 177, 1124-1135.e1116. [CrossRef] [PubMed]

49. Greenberg, S.B.; Criswell, B.S.; Six, H.R.; Couch, R.B. Lymphocyte cytotoxicity to influenza virus-infected cells: Response to vaccination and virus infection. Infect. Immun. 1978, 20, 640-645. [CrossRef] [PubMed]

50. Greenberg, S.B.; Six, H.R.; Drake, S.; Couch, R.B. Cell cytotoxicity due to specific influenza antibody production in vitro after recent influenza antigen stimulation. Proc. Natl. Acad. Sci. USA 1979, 76, 4622-4626. [CrossRef] [PubMed]

51. Meguro, H.; Kervina, M.; Wright, P.F. Antibody-Dependent Cell-Mediated Cytotoxicity against Cells Infected with Respir-atory Syncytial Virus: Characterization of in Vitro and In Vivo Properties. J. Immunol. 1979, 122, 2521. [PubMed]

52. Scott, R.; de Landazuri, M.O.; Gardner, P.S.; Owen, J.J. Human antibody-dependent cell-mediated cytotoxicity against target cells infected with respiratory syncytial virus. Clin. Exp. Immunol. 1977, 28, 19-26.

53. Vella, S.; Rocchi, G.; Resta, S.; Marcelli, M.; De Felici, A. Antibody reactive in antibody-dependent cell-mediated cytotoxicity following influenza virus vaccination. J. Med. Virol. 1980, 6, 203-211. [CrossRef]

54. Von Holle, T.A.; Moody, M.A. Influenza and Antibody-Dependent Cellular Cytotoxicity. Front. Immunol. 2019, 10, 1457. [CrossRef]

55. Collins, A.M. IgG subclass co-expression brings harmony to the quartet model of murine IgG function. Immunol. Cell Biol. 2016, 94, 949-954. [CrossRef]

56. Khanna, M.; Jackson, R.J.; Alcantara, S.; Amarasena, T.H.; Li, Z.; Kelleher, A.D.; Kent, S.J.; Ranasinghe, C. Mucosal and systemic SIV-specific cytotoxic CD4+ T cell hierarchy in protection following intranasal/intramuscular recombinant pox-viral vaccination of pigtail macaques. Sci. Rep. 2019, 9, 5661. [CrossRef]

57. Panagioti, E.; Klenerman, P.; Lee, L.N.; van der Burg, S.H.; Arens, R. Features of Effective T Cell-Inducing Vaccines against Chronic Viral Infections. Front. Immunol. 2018, 9, 276. [CrossRef] [PubMed]

58. Stark, G.R.; Kerr, I.M.; Williams, B.R.; Silverman, R.H.; Schreiber, R.D. How cells respond to interferons. Annu. Rev. Biochem. 1998, 67, 227-264. [CrossRef] [PubMed]

59. Hem, S.L.; Harm, H. Aluminum-Containing Adjuvants: Properties, Formulation, and Use. In Vaccine Adjuvants and Delivery Systems; Wiley: Hoboken, NJ, USA, 2007; pp. 81-114. [CrossRef]

60. Al-Shakhshir, R.H.; Regnier, F.E.; White, J.L.; Hem, S.L. Contribution of electrostatic and hydrophobic interactions to the adsorption of proteins by aluminium-containing adjuvants. Vaccine 1995, 13, 41-44. [CrossRef]

61. Jully, V.; Mathot, F.; Moniotte, N.; Préat, V.; Lemoine, D. Mechanisms of Antigen Adsorption Onto an Aluminum-Hydroxide Adjuvant Evaluated by High-Throughput Screening. J. Pharm. Sci. 2016, 105, 1829-1836. [CrossRef]

62. Chang, C.B.; Knobler, C.M.; Gelbart, W.M.; Mason, T.G. Curvature dependence of viral protein structures on encapsidated nanoemulsion droplets. ACS Nano. 2008, 2, 281-286. [CrossRef]

63. Chesko, J.; Kazzaz, J.; Ugozzoli, M.; O'Hagan, D.T.; Singh, M. An investigation of the factors controlling the adsorption of protein antigens to anionic PLG microparticles. J. Pharm. Sci. 2005, 94, 2510-2519. [CrossRef]

64. Fox, C.B.; Kramer, R.M.; Barnes, V.L.; Dowling, Q.M.; Vedvick, T.S. Working together: Interactions between vaccine antigens and adjuvants. Ther. Adv. Vaccines 2013, 1, 7-20. [CrossRef]

65. Watson, D.S.; Endsley, A.N.; Huang, L. Design considerations for liposomal vaccines: Influence of formulation parameters on antibody and cell-mediated immune responses to liposome associated antigens. Vaccine 2012, 30, 2256-2272. [CrossRef] 
66. Watson, D.S.; Platt, V.M.; Cao, L.; Venditto, V.J.; Szoka, F.C., Jr. Antibody response to polyhistidine-tagged peptide and protein antigens attached to liposomes via lipid-linked nitrilotriacetic acid in mice. Clin. Vaccine Immunol. 2011, 18, 289-297. [CrossRef]

67. Hansen, B.; Malyala, P.; Singh, M.; Sun, Y.; Srivastava, I.; Hogenesch, H.; Hem, S.L. Effect of the strength of adsorption of HIV 1 SF162dV2gp140 to aluminum-containing adjuvants on the immune response. J. Pharm. Sci. 2011, 100, 3245-3250. [CrossRef]

68. Ozorowski, G.; Cupo, A.; Golabek, M.; LoPiccolo, M.; Ketas, T.A.; Cavallary, M.; Cottrell, C.A.; Klasse, P.J.; Ward, A.B.; Moore, J.P. Effects of Adjuvants on HIV-1 Envelope Glycoprotein SOSIP Trimers In Vitro. J. Virol. 2018, 92, e00381-18. [CrossRef] [PubMed]

69. Funchal, G.A.; Jaeger, N.; Czepielewski, R.S.; Machado, M.S.; Muraro, S.P.; Stein, R.T.; Bonorino, C.B.C.; Porto, B.N. Respiratory syncytial virus fusion protein promotes TLR-4-dependent neutrophil extracellular trap formation by human neutrophils. PLoS ONE 2015, 10, e0124082. [CrossRef] [PubMed]

70. Liu, W.-C.; Lin, S.-C.; Yu, Y.-L.; Chu, C.-L.; Wu, S.-C. Dendritic Cell Activation by Recombinant Hemagglutinin Proteins of H1N1 and H5N1 Influenza $A$ Viruses. J. Virol. 2010, 84, 12011. [CrossRef] [PubMed]

71. Modhiran, N.; Watterson, D.; Muller, D.A.; Panetta, A.K.; Sester, D.P.; Liu, L.; Hume, D.A.; Stacey, K.J.; Young, P.R. Dengue virus NS1 protein activates cells via Toll-like receptor 4 and disrupts endothelial cell monolayer integrity. Sci. Transl. Med. 2015, 7, 304ra142. [CrossRef] [PubMed]

72. Rallabhandi, P.; Phillips, R.L.; Boukhvalova, M.S.; Pletneva, L.M.; Shirey, K.A.; Gioannini, T.L.; Weiss, J.P.; Chow, J.C.; Hawkins, L.D.; Vogel, S.N.; et al. Respiratory Syncytial Virus Fusion Protein-Induced Toll-Like Receptor 4 (TLR4) Signaling Is Inhibited by the TLR4 Antagonists Rhodobacter sphaeroides Lipopolysaccharide and Eritoran (E5564) and Requires Direct Interaction with MD-2. mBio 2012, 3, e00218-12. [CrossRef] [PubMed]

73. Bieback, K.; Lien, E.; Klagge, I.M.; Avota, E.; Schneider-Schaulies, J.; Duprex, W.P.; Wagner, H.; Kirschning, C.J.; Ter Meulen, V.; Schneider-Schaulies, S. Hemagglutinin protein of wild-type measles virus activates toll-like receptor 2 signaling. J. Virol. 2002, 76, 8729-8736. [CrossRef]

74. Hiatt, A.; Bohorova, N.; Bohorov, O.; Goodman, C.; Kim, D.; Pauly, M.H.; Velasco, J.; Whaley, K.J.; Piedra, P.A.; Gilbert, B.E.; et al. Glycan variants of a respiratory syncytial virus antibody with enhanced effector function and in vivo efficacy. Proc. Natl. Acad. Sci. USA 2014, 111, 5992. [CrossRef]

75. Lu, Y.; Welsh, J.P.; Swartz, J.R. Production and stabilization of the trimeric influenza hemagglutinin stem domain for potentially broadly protective influenza vaccines. Proc. Natl. Acad. Sci. USA 2014, 111, 125. [CrossRef]

76. Valkenburg, S.A.; Mallajosyula, V.V.A.; Li, O.T.W.; Chin, A.W.H.; Carnell, G.; Temperton, N.; Varadarajan, R.; Poon, L.L.M. Stalking influenza by vaccination with pre-fusion headless HA mini-stem. Sci. Rep. 2016, 6, 22666. [CrossRef]

77. DiLillo, D.J.; Palese, P.; Wilson, P.C.; Ravetch, J.V. Broadly neutralizing anti-influenza antibodies require Fc receptor engagement for in vivo protection. J. Clin. Investig. 2016, 126, 605-610. [CrossRef]

78. Sedova, E.S.; Scherbinin, D.N.; Lysenko, A.A.; Alekseeva, S.V.; Artemova, E.A.; Shmarov, M.M. Non-neutralizing Antibodies Directed at Conservative Influenza Antigens. Acta Nat. 2019, 11, 22-32. [CrossRef] [PubMed]

79. Zhang, N.; Channappanavar, R.; Ma, C.; Wang, L.; Tang, J.; Garron, T.; Tao, X.; Tasneem, S.; Lu, L.; Tseng, C.-T.K.; et al. Identification of an ideal adjuvant for receptor-binding domain-based subunit vaccines against Middle East respiratory syndrome coronavirus. Cell Mol. Immunol. 2016, 13, 180-190. [CrossRef] [PubMed]

80. Park, S.A.; Song, E.S.; Cho, Y.J.; Ahn, B.Y.; Ha, S.-H.; Seong, B.L.; Lee, K.H.; Lee, N.G. Immune Responses of Mice to Influenza Subunit Vaccine in Combination with CIA07 as an Adjuvant. Microbiol. Immunol. 2007, 51, 1099-1107. [CrossRef] [PubMed]

81. Williams, M.A.; Holmes, B.J.; Sun, J.C.; Bevan, M.J. Developing and maintaining protective CD8+ memory T cells. Immunol. Rev. 2006, 211, 146-153. [CrossRef] [PubMed]

82. Seder, R.A.; Darrah, P.A.; Roederer, M. T-cell quality in memory and protection: Implications for vaccine design. Nat. Rev. Immunol. 2008, 8, 247-258. [CrossRef]

83. Zimmerli, S.C.; Harari, A.; Cellerai, C.; Vallelian, F.; Bart, P.-A.; Pantaleo, G. HIV-1-specific IFN- $\gamma /$ IL-2-secreting CD8 T cells support CD4-independent proliferation of HIV-1-specific CD8 T cells. Proc. Natl. Acad. Sci. USA 2005, 102, 7239. [CrossRef]

84. Lichterfeld, M.; Yu, X.G.; Waring, M.T.; Mui, S.K.; Johnston, M.N.; Cohen, D.; Addo, M.M.; Zaunders, J.; Alter, G.; Pae, E.; et al. HIV-1-specific cytotoxicity is preferentially mediated by a subset of CD8+ T cells producing both interferon- $\gamma$ and tumor necrosis factor- $\alpha$. Blood 2004, 104, 487-494. [CrossRef]

85. Teijaro, J.R.; Turner, D.; Pham, Q.; Wherry, E.J.; Lefrançois, L.; Farber, D.L. Cutting Edge: Tissue-Retentive Lung Memory CD4 T Cells Mediate Optimal Protection to Respiratory Virus Infection. J. Immunol. 2011, 187, 5510. [CrossRef]

86. Van de Sandt, C.E.; Kreijtz, J.H.C.M.; de Mutsert, G.; Geelhoed-Mieras, M.M.; Hillaire, M.L.B.; Vogelzang-van Trierum, S.E.; Osterhaus, A.D.M.E.; Fouchier, R.A.M.; Rimmelzwaan, G.F. Human Cytotoxic T Lymphocytes Directed to Seasonal Influenza A Viruses Cross-React with the Newly Emerging H7N9 Virus. J. Virol. 2014, 88, 1684. [CrossRef]

87. Zhou, X.; Hopkins, J.W.; Wang, C.; Brahmakshatriya, V.; Swain, S.L.; Kuchel, G.A.; Haynes, L.; McElhaney, J.E. IL-2 and IL-6 cooperate to enhance the generation of influenza-specific CD8 T cells responding to live influenza virus in aged mice and humans. Oncotarget 2016, 7, 39171-39183. [CrossRef]

88. Strutt, T.M.; Dhume, K.; Finn, C.M.; Hwang, J.H.; Castonguay, C.; Swain, S.L.; McKinstry, K.K. IL-15 supports the generation of protective lung-resident memory CD4 T cells. Mucosal Immunol. 2018, 11, 668-680. [CrossRef] [PubMed]

89. Strutt, T.M.; McKinstry, K.K.; Kuang, Y.; Bradley, L.M.; Swain, S.L. Memory CD4 T-cell-mediated protection depends on secondary effectors that are distinct from and superior to primary effectors. Proc. Natl. Acad. Sci. USA 2012, 109, E2551. [CrossRef] [PubMed] 
90. Quiñones-Parra, S.; Grant, E.; Loh, L.; Nguyen, T.H.O.; Campbell, K.-A.; Tong, S.Y.C.; Miller, A.; Doherty, P.C.; Vijaykrishna, D.; Rossjohn, J.; et al. Preexisting CD8 T-cell immunity to the H7N9 influenza A virus varies across ethnicities. Proc. Natl. Acad. Sci. USA 2014, 111, 1049. [CrossRef] [PubMed]

91. Wang, Z.; Wan, Y.; Qiu, C.; Quiñones-Parra, S.; Zhu, Z.; Loh, L.; Tian, D.; Ren, Y.; Hu, Y.; Zhang, X.; et al. Recovery from severe H7N9 disease is associated with diverse response mechanisms dominated by CD8+ T cells. Nat. Commun. 2015, 6, 6833. [CrossRef]

92. Hemann, E.A.; Kang, S.-M.; Legge, K.L. Protective CD8 T Cell-Mediated Immunity against Influenza A Virus Infection following Influenza Virus-like Particle Vaccination. J. Immunol. 2013, 191, 2486. [CrossRef]

93. Li, Z.; Khanna, M.; Grimley, S.L.; Ellenberg, P.; Gonelli, C.A.; Lee, W.S.; Amarasena, T.H.; Kelleher, A.D.; Purcell, D.F.J.; Kent, S.J.; et al. Mucosal IL-4R antagonist HIV vaccination with SOSIP-gp140 booster can induce high-quality cytotoxic CD4+/CD8+ T cells and humoral responses in macaques. Sci. Rep. 2020, 10, 22077. [CrossRef] 